\title{
Evlilik İlişkisinin Gizil Güçleri: Özgecil Aşk, Acının Dönüştürücü Gücü ve Fedakârlık Doyumu
}

\section{The Secret Powers of Marital Relationship: Agapic Love, Transformative Power of Suffering and Satisfaction with Sacrifice}

Duygu Dinçer a,", Didem Aydoğan ${ }^{b}$

a Dr. Öğr. Üyesi, İstanbul Aydın Üniversitesi, Eğitim Fakültesi, Eğitim Bilimleri Bölümü, 34295, İstanbul/Türkiye. ORCID: 0000-0003-2496-6902

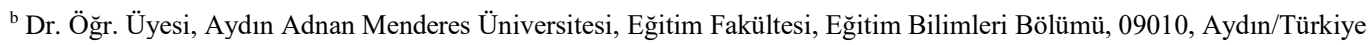
ORCID: 0000-0002-7163-3003

\begin{tabular}{l} 
MAKALE BİLGİSI \\
\hline Makale Geçmişi: \\
Başvuru tarihi: 01 Ocak 2019 \\
Düzeltme tarihi: 11 Mayıs 2019 \\
Kabul tarihi: 27 Mayıs 2019 \\
Anahtar Kelimeler: \\
Fedakârlık doyumu \\
Fedakârlık davranışları \\
Özgecil aşk \\
Acının dönüştürücü gücü \\
Cinsiyet
\end{tabular}

\section{A R T I C L E IN F O}

\section{Article history:}

Received: 01 January 2019

Received in revised form: 11 May 2019

Accepted: 27 May 2019

\section{Keywords:}

Satisfaction with sacrifice

Sacrifice behaviors

Agape

Transformative power of suffering

Gender
ÖZ

$\mathrm{Bu}$ çalışmanın ilk amacı, evlilik ilişsisinde ne tür fedakârlık davranışları sergilendiğini ve bu davranışların cinsiyete göre farklılık gösterip göstermediğini keşfetmektir. İkinci amacı ise evlilik ilişkisinde sergilenen fedakârlık davranışlarından alınan doyum ile özgecil aşk arasındaki ilişkiyi ve bu ilişkide acının dönüştürücü gücünün aracı etkisini incelemektir. Araştırmada 318 evli katılımcıdan veri toplanmıştır. Elde edilen sonuçlar, fedakârlık davranışlarının gündelik fedakârlıklar (örneğin günlük işler, iletişim ve etkileşim) ve büyük fedakârlıklar (örneğin işini ve yerleşim yerini değiştirme gibi) olmak üzere iki tema altında gruplandığını göstermiştir. İkinci amaç doğrultusunda elde edilen sonuçlar özgecil aşk, acının dönüştürücü gücü ve fedakârlık doyumu arasında pozitif yönde anlamlı ilişkiler olduğunu ortaya koymuştur. Ayrıca özgecil aşkın, fedakârlık doyumunu doğrudan ve dolaylı olarak (acının dönüştürücü gücü aracılığıyla) yordadığı saptanmıştır.

\section{Giriş}

Romantik ilişkiler, tarafların birbirinin istek ve ihtiyaçlarına duyarlı olmasını gerektiren, paylaşıma dayalı ilişkilerdir. Bu ortaklaşa paylaşıma dayalı yapı, partnerin ya da ilişkinin iyi oluşu için kişinin zaman zaman kendi anlık istek ve çıkarlarından feragat etmesini ve çeşitli fedakârlıklarda bulunmasını gerektirmektedir (Impett ve Gordon, 2008;

* Sorumlu yazar/Corresponding author

e-posta: duygudincer@aydin.edu.tr 
Kogan, Impett, Oveis, Hui, Gordon ve Keltner, 2010). Önceki araştırmalar fedakârlı̆̆ı, "kişinin partneri ya da ilişkisi uğruna kişisel çıkarlarından vazgeçmesi" (Van Lange, Rusbult, Drigotas, Arriaga, Witcher ve Cox, 1997), ilişskisini devam ettirmek için kendini keyif aldığ aktivitelerden (örneğin aynı cinsten arkadaşlarla vakit geçirmek) alıkoyması, partnerinin yararına kendi istek, ihtiyaç ve amaçlarını ikinci plana alması (Killen ve Turiel, 1998), bu nedenle istemediği davranışları sergilemesi ya da arzu etmediği etkinliklere yönelmesi (örneğin partnerine eşlik etmek için tanıdığ katılmak) olarak tanımlayıp merkezine pasif, hipotetik ve büyük fedakârlık durumlarını yerleştirirken; Impett, Gable ve Peplau (2005) tarafından yürütülen araştırmalar, fedakârlığı pozitif bir ilişki gücü olarak tanımlayıp hem ilişki içindeki bireylere hem de ilişkinin kendisine fayda sağlayan aktif ve gündelik fedakârlık durumlarına odaklanmıştır.

Bununla birlikte son yıllarda araştırmacıların daha çok, bireyleri fedakârlık davranışına güdüleyen etmenler üzerinde durmaya başladığı görülmektedir (Kogan vd., 2010). Örneğin, Gable ve Reis (2001) ile Impett ve diğerleri (2005) yakın ilişkilerde sergilenen fedakârlık davranışlarını yaklaşma ve kaçınma olmak üzere iki güdü üzerinden açıklamaktadır. Yaklaşma motivasyonuyla yapılan fedakârlık davranışlarında partneri mutlu etme ve onunla daha yakın ilişki içinde olma; kaçınma motivasyonuyla yapılan fedakârlık davranışlarında ise partner tarafından onaylanmama ya da onun ilgisini kaybetme gibi olumsuz sonuçlardan ve ilişkide ortaya çıkabilecek çatışmalardan geri durma niyeti bulunmaktadır. Visserman, Righetti, Impett, Keltner ve Van Lange (2017) ise fedakârlık davranışlarını altı farklı motivasyon üzerinden açıklamaktadır: Bunlardan üçü yaklaşma motivasyonuna [(I) partner odaklı yaklaşma motivasyonu (örneğin partneri mutlu etmek için sergilenmektedir), (II) ilişki odaklı yaklaşma motivasyonu (örneğin kişilerarası yakınlığı arttırmak için sergilenmektedir), (III) kendi odaklı yaklaşma motivasyonu (örneğin kişinin cömert bir insan olduğu konusunda kendisini iyi hissetmesi için sergilenmektedir)]; diğer üçü kaçınma motivasyonuna [(I) partner odaklı kaçınma motivasyonu (örneğin partneri üzmekten kaçınmak için sergilenmektedir), (II) ilişki odaklı kaçınma motivasyonu (örneğin ilişkinin sonlanmasından kaçınmak için sergilenmektedir) ve son olarak (III) kendi odaklı kaçınma motivasyonu (örneğin kendini suçlu hissetmekten kaçınmak için sergilenmektedir)] dayalıdır. $\mathrm{Bu}$ doğrultuda yapılan araştırmalar, romantik ilişkilerde istenmeyen sonuçlardan ve olumsuz tepki görmekten kaçınmak amacıyla ya da kendi ihtiyaçlarını hiçe sayarak gerçekleştirilen fedakârlık davranışlarının mutsuzluk ve küskünlük gibi negatif duygular yaratarak ilişki kalitesini azalttığını (Neff ve Harter, 2002), iyi oluşa zarar verdiğini ve depresyona yol açtığını (Jack, 1991; Lerner, 1988); spontan ve otantik bir şekilde yapılan fedakârlık davranışlarının ise ilişkileri pozitif yönde etkilediğini ortaya koymuştur (Aydoğan ve Özbay, 2018; Bahr ve Bahr, 2001; Batson, Bolen, Cross ve Neuringer-Benefiel, 1986; Stanley ve Markman, 1992; Stanley, Whitton, Sadberry, Clements ve Markman, 2006; Van Lange, Agnew, Harinck ve Steemers, 1997). Bahsi geçen bulguların ortaya çıkmasında yaklaşma ve kaçınma motivasyonları kadar fedakârlık yapmaya istekli olmak da önemlidir. Çünkü bu isteklilik, çoğu zaman, sergilenen fedakârlık davranışlarından ve onların ilişkisel ya da duygusal çıktılarından doyum almayı beraberinde getirmektedir. Aynı zamanda kişinin fedakârlık davranışında bulunma motivasyonunu pekiştirmektedir (Kogan vd., 2010). Yapılan araştırmalar ilişki kalitesi, kendini açma, adanmışlık (Stanley ve Markman, 1992; Van Lange vd., 1997) gibi ilişki dinamikleri ile partnerin ve ilişkinin iyi oluşu için dua etme gibi dinsel pratiklerin (Lambert, Fincham ve Stanley, 2012) fedakârlıktan alınan doyumla pozitif yönde ilişkili olduğunu ortaya koymuştur. Türkiye'de de fedakârlığı ve fedakârlıktan alınan doyumu incelemeye dönük çeşitli araştırmaların yapıldığı görülmektedir. Sınırlı sayıda olan bu araştırmalarda ilişkisel özgünlük arttıkça fedakârlık doyumunun, fedakârlık doyumu arttıkça evlilik doyumunun arttığı (Aydoğan ve Özbay, 2018) ve fedakârlıktan alınan doyum ile eş tükenmişliğinin ilişkili olduğu (Yaman ve Eryiğit, 2018) saptanmıştır. Şimdiki çalışma evlilikte sergilenen fedakârlık davranışlarından alınan doyumu özgecil aşk ve acının dönüştürücü gücü ile ilişkileri bağlamında inceleyerek varolan bilgi birikimini genişletmeyi hedeflemektedir.

\section{Fedakârlık Davranışları ve Cinsiyet Olgusu}

Evlilik ilişkisi, karşılıklı bağımlı benlik yapısına (Day ve Impett, 2017) ve bakıma dayalı bir ilişki dinamiğine (Clark ve Mills, 1979) sahip olduğu için, partnerlerin sik s1k fedakârlık davranışında bulunduğu görülmektedir (Bar-Tal, 1976; Killen ve Turiel, 1998). Impett ve diğerleri (2005) tarafından yürütülen araştırmalar, evlilik ilişkisinde sergilenen fedakârlık davranışlarının genel olarak iki ana alanda toplandığını ortaya koymaktadır: Gündelik (küçük) fedakârlıklar ve büyük fedakârlıklar. Gündelik fedakârlıklar alanı günlük işler, iletişim ve etkileşim, aile, para ve hediyeler, sağlık, yaşam tarzı ve gelecek planları, okul ve iş, eğlence ve boş zaman etkinlikleri, görünüm, fiziksel ve cinsel yakınlık, diğer cinsle ilişkiler gibi konuları; büyük fedakârlıklar alanı ise iş ve yerleşim yeri değişiklikleri, iş hayatına ya da eğitim hayatına ara/son verme gibi konuları kapsamaktadır. Yapılan araştırmalar ilişkisel adanmışlık ve kalıcılık beklentisi arttıkça bahsi geçen fedakârlık davranışlarının arttığını (Stanley ve Markman, 1992; Van Lange vd., 1997) ve bu davranışlar arttıkça çift kimliğinin (Aron, Aron, Tudor ve Nelson, 1991) ve ilişskisel işlevselliğin güçlendiğini ortaya koymuştur (Rusbult, Verette, Whitney, Slovik ve Lipkus, 1991).

Buna karşın feminist araştırmacılar fedakârlığın negatif yanlarına dikkat çekmiş ve kadınlara verdiği zarara odaklanmıştır (Jack, 1991; Lerner, 1988; Whitton, Stanley ve Markman, 2007). Örneğin Lerner (1988) kadınların ilişkilerinin devamlılığını sağlamak için fedakârlıkta bulunma zorunluluğu hissetmesinin depresyonun temel yordayıcılarından biri olduğunu ortaya koymuştur. Jack (1991) ise kadınların diğerlerinin ihtiyaçlarını kendi ihtiyaçlarının önünde tutma ve bu bağlamda kendini ihmal etme eğiliminin depresyona yakalanma riskini arttırdığını bulgulamıştır. Buna karşın Page, Stevens ve Galvin (1996) ilişkinin devamlılığını sağlamak için yapılan fedakârlık davranışlarının sadece kadınlarda değil, erkeklerde de depresyona yakalanma riskini arttırdığını saptamıştır. Sakall1-Uğurlu ve Türkoğlu (2017) ise Türkiye'de yürüttükleri bir araştırmada evli kadınlarla ilgili en güçlü kalıpyargının "fedakâr ve cefakâr olma" olduğunu tespit etmiştir. Bu bulgu, Türk kültüründe evli bir kadından "fedakârlık" beklendiğine işaret etmesi bakımından 
önemlidir çünkü ortaya çıkan fedakârlık kalıpyargısının kadınlarda, Lerner'ın (1988) dikkat çektiği gibi, ilişkilerinin devamlılığını sağlamak için fedakârlıkta bulunma zorunluluğu hissi yaratması muhtemeldir.

Yukarıdaki açıklamalar fedakârlık davranışlarında cinsiyet faktörünü göz önünde tutmaya ihtiyaç olduğunu göstermektedir. Alanyazında eşlerin birbiri için yaptığ büyük fedakârlıkları listelemesini isteyen çeşitli araştırmalar bulunmakla birlikte (bkz. Van Lange vd., 1997; Van Lange, Rusbult, vd., 1997) gündelik fedakârlık davranışlarını inceleyen az sayıda çalışmaya rastlanmaktadır (bkz. Impett vd., 2005). Şimdiki çalışma bireylerin eşleri için yaptığı gündelik ve büyük fedakârlıkları inceleyerek toplulukçu bir kültür içinden elde edilen bulgularla fedakârlık alanyazının genişlemesine katkıda bulunmaktadır. Ayrıca ilişki dinamiklerini önemli ölçüde etkilediği düşünülen fedakârlık davranışlarının evlilik yaşamında ne sıklıkla sergilendiğini ve bu davranışların cinsiyete göre farklılaşıp farklılaşmadığını küçük bir çalışma grubu üzerinden araştırmayı amaçlamaktadır.

\section{Fedakârlık ve Özgecil Aşk}

En derin ve anlamlı duygulardan biri olan aşk (Rubin, 1970) hem romantik ilişkilerin gelişmesi ve sürdürülmesinde (Dion ve Dion, 1996) hem de evlilik ideolojisinin şekillenmesinde rol oynayan önemli kavramlardan biridir (Edgar ve Glezer, 1994). Pek çok insan aşk ilişkisi olmadığı sürece evlenmeyi tercih etmemekte (Levine, Sato, Hashimoto ve Verma, 1995; Sprecher ve Toro-Morn, 2002); birçok evlilik aşk bittiği için sona ermektedir. Yetişkin yaşamında böylesine kritik bir yeri olan aşk (Lin ve Huddleston-Cassas, 2005), psikoloji alanyazınının gündemini de önemli ölçüde meşgul etmektedir. Mevcut alanyazın incelendiğinde pek çok aşk kuramı bulunduğu görülmektedir (bkz. Aşkın Üçgeni Teorisi için Sternberg, 1986; Aşkın Renkleri Kuramı için Lee, 1977/1973, 1977 ve Hendrick ve Hendrick, 1986, 1990; Romantik Aşk ve Hoşlanma için Rubin, 1970; Yetişkin Bağlanma Tarzları ve Aşk Kuramı için Shaver ve Hazan, 1987; Tutkulu Aşk için Hatfield ve Sprecher, 1986; Prototip Aşk Yaklaşımı için Fehr ve Russell, 1991). Bu aşk yaklaşımları arasında alanyazında en fazla test edilenin Lee'nin (1977/1973) Aşkın Renkleri Kuramı olduğu gözlenmektedir (Kanemasa, Taniguchi, Daibo ve Ishimori, 2004; Thompson ve Borello, 1992). Aşkın Renkleri Kuramı'na göre üçü birincil [Eros (tutkulu aşk), Ludus (oyunsu/oyunbaz aşk) ve Storge (arkadaşça aşk)], üçü ikincil [Mania (sahiplenici aşk), Pragma (pragmatik, alışveriş listesi aşkl) ve Agape (özgecil aşk)] olmak üzere aşka ilişkin toplam altı tutum vardır. Şimdiki çalışma aşkı bu kuramsal çerçeveden hareketle ele almaktadır. Ancak altı aşk tarzından yalnızca birine, özgecil aşka odaklanmaktadır; çünkü özgecil aşk, aşkın fedakârlık içeren öteki-merkezli yapısını (Hill, 2002) yansıtmaktadır. Alanyazında, elbette, aşkın fedakârlık içeren doğasına vurgu yapan Lee'den başka araştırmacılar da vardır. Örneğin Noller (1996) aşkı bakım, güven, saygı ve sadakat gibi kavramların yanı sıra fedakârlık kavramıla da tanımlamakta; Pam, Plutchik ve Conte (1973) özgecilliği aşkın en tipik özelliklerinden biri olarak nitelemekte; Kelley ve Thibault (1978) sağlıklı romantik ilişkilerin temel özelliklerinden birinin fedakârlık olduğunu ileri sürmektedir. Özgecil olmanın aşkın doğasında oynadığı bu kilit rol göz önünde bulundurulduğunda, evlilikte fedakârlık araştırmalarında ele alınması gereken değişkenlerden birinin özgecil aşk olması gerektiği düşünülmektedir.

Lee'nin $(1977 / 1973 ; 1977)$ özgecil aşk kavramsallaştırması, koşulsuz, bencillikten uzak, adanmış ve fedakârca aşkı temel almaktadır. Kurama göre, bu aşk tarzına sahip olan bir âşık, partnerine bakım ve özen göstermeyi, onun ihtiyaçlarına karşı duyarlı olmayı ve bu ihtiyaçları karşılaşmayı kutsal bir görev saymaktadır. Köken olarak Hıristiyanlıktaki kendini kurban eden sevgiyle ilişkilendirilen özgecil aşk, düşmanı bile sevmeyi salık veren ruhanî ve ilahî bir aşk anlayışı üzerine kuruludur ve bu nedenle uzun yıllar din adamları tarafından desteklenmiştir (Lee, 1975). Din, dinsellik ve özgecil aşk arasındaki ilişki, güncel araştırmalar tarafından da mercek altına alınmaktadır. Örneğin Hendrick ve Hendrick (1987) özgecil, arkadaşça ve pragmatik aşkın tutkulu, oyunsu ve sahiplenici aşka göre dinsellikle daha yüksek düzeyde ilişkili olduğunu saptamıştır. Montgomery ve Sorell (1997), özgecil âşıların kiliseye daha fazla gittiğini bulgulamıştır. Lin ve Huddleston-Cassas (2005) Hıristiyanlığın farklı mezheplerine mensup katılımcılarla yürüttüğü çalışmada özgecil aşkla dinsellik arasında pozitif yönde anlamlı bir ilişki olduğunu saptamıştır. Bu bulgular, özgecil aşkın bireylerin spritüel yönleriyle ilişkili olduğuna işaret etmektedir. Yapılan araştırmalar ayrıca özgecil aşk tarzına en çok evli çiftlerde rastlandığını (Montogomery ve Sorell, 1997), bu aşk tarzının ilişkideki yakınlık hissini (Dinçer, 2017) ve evlilik doyumunu arttırdığını ortaya koymuştur (Lin ve Huddleston-Cassas, 2005; Martin, Blair, Nevels ve Fitzpatrick, 1990). Tüm bu bulgulardan hareketle şimdi çalışma özgecil aşkın hem yukarıda bahsi geçen spritüel doğası hem de fedakârlığı merkezine alan yapısı nedeniyle acının dönüştürücü gücü ve fedakârlık doyumu ile ilişkili olduğunu öngörmekte ve bunu evli bireyler üzerinden incelemektedir.

\section{Fedakârlık ve Acının Dönüştürücü Gücü}

Zorlukların, olumsuz, 1stırap verici ve travmatik yaşam olaylarının ardından pozitif yönde değişimler yaşanacağına ilişkin kişisel inançları ifade eden acının dönüştürücü gücü kavramı (Dinçer, 2018; Dinçer, Ekşi, Demirci ve Kardaş, 2015; Ekşi, Dinçer ve Akalp, 2017; Joshanloo, 2014, 2015; Tedeschi ve Calhoun, 1996), yakın ilişkiler açısından da ele alınması gereken önemli konulardan biridir. Kavramı, pozitif psikoloji bağlamında ele alan Joshanloo'ya (2014) göre acının dönüştürücü gücü ile ilgili inançlar; acıların kişiyi olgunlaştırdığı ve sabırla karşılanırsa hakiki mutlulukların kap1 aralayıcısı olacağı, yani mutluluğa ulaşmak için zorluklara katlanmak gerektiği konusundaki inançları yansıtmaktadır. $\mathrm{Bu}$ perspektiften bakıldığında yaşamda karşılaşılan kriz durumlarının altından başarıyla kalkabilmek kişi için kendini aşma ve olgunlaşma imkânıdır.

Acıya yüklenen pozitif anlamlar, bireylerin en önemli içsel kaynaklarından ve spritüel güçlerinden birini oluşturmaktadır; çünkü onları olumsuz yaşam olayları karşısında dayanıklı ve hazır kılmaktadır (Dinçer vd., 2015; Jayawickreme ve Blackie, 2016). Yapılan araştırmalar, Saint Paul'e atfedilen "Acı çekme dayanıklılığı, dayanıklılık karakteri, karakter ise umudu inşa eder." ya da Friedrich Nietzsche'ye atfedilen "Beni öldürmeyen şey, güçlendirir" sözlerini destekler şekilde (akt. Jayawickreme ve Blackie, 2016) bireylerin, yaşadıkları olumsuz yaşam olaylarının ardından pozitif değişimler deneyimlediğini ortaya 
koymaktadır. Örneğin bazı araştırmalarda, bireylerin yaşadıkları olumsuz olayların ardından çevresindeki insanlarla daha güçlü bağlar kurduğu (Joseph ve Linley, 2008; Tedeschi ve Calhoun, 2004), hayattaki küçük şeylerden daha fazla mutlu olduğu (Tedeschi ve Calhoun, 2004), kendini daha güçlü ve olgun hissettiği ve yaşamın değerini daha iyi anlamaya başladığı görülmüştür (Tedeschi ve Calhoun, 1996). Bu inançlar bireyden bireye, kültürden kültüre değişkenlik göstermekle birlikte birçok dini gelenekte, örneğin İslam geleneğinde, Hinduizm'de, Budizm'de (Tedesci ve Calhoun, 1995), eski Yunan'da, Musevilikte, Hristiyan teolojisinde, mistisizmde ve Sibirya Şamanizmi'nde (Scrutton, 2015) sik s1k işlenmektedir (Tedesci ve Calhoun, 1995).

Psikoloji alanyazınında ise acının dönüştürücü gücü görece yeni bir kavramdır ve gerek dünyada gerekse Türkiye'de üzerine henüz pek fazla araştırma bulunmamaktadır. Varolan araştırmalarınsa daha çok bireysel dinamikler üzerine yoğunlaştığ1 görülmektedir. Örneğin acının dönüştürücü gücünün psikolojik sağlamlık, yaşam doyumu (Dinçer vd., 2014) ve aşırı koruyucu ebeveyn tutumlarıyla (Ekşi vd., 2017) ilişkili olduğu tespit edilmiştir. Şimdiki çalışmada ise acının dönüştürücü gücüne ilişkin inançların evlilik ilişkisinde sergilenen fedakârlık davranışlarından alınan doyumu yordayacağı öngörülmektedir. Başka bir deyişle zor tecrübelere yüklenen pozitif anlamların, evlilik ilişkisinde karşılaşılan güçlüklere gögüs germede, bu güçlüklerin üstesinden gelmede, kişiyi fedakârlık davranışında bulunmaya ve bu davranışlardan doyum almaya güdülemede spritüel bir iç güç olarak etkili olacağ 1 düşünülmektedir. Zira bu inançların kişide, fedakârlıkların sonunda daha güçlü bir ilişkisel iyi oluşa ulaşılacağı yönünde bir umut uyandırması muhtemeldir. $\mathrm{Bu}$ öngörüyle tutarlı şekilde, yapılan araştırmalar bireylerde fedakârlıkların bir gün karşılık bulacağı ve ilişki kalitesini arttıracağı beklentisi arttıkça fedakârlıkta bulunma davranışının arttığını ortaya koymaktadır (Johnson, Caughlin ve Huston, 1999; Levinger, 1980).

\section{5. Şimdiki Çalışma}

Şimdiki çalışma, ilk olarak, evlilik ilişkisinde ne tür fedakârlık davranışları sergilendiğini ve bu davranışların cinsiyete göre farklılaşıp farklılaşmadığını keşfetmeyi amaçlamaktadır. Bu amaçla "Bireyler evliliklerinde ne tür fedakârlık yaşantıları deneyimlemektedir?" ve "Kadın ve erkeklerin fedakârlık yaşantılarındaki benzerlik ve farklılıklar nelerdir?" sorularına cevap aranmaktadır. Böylece Impett ve diğerlerinin (2005) ortaya koyduğu fedakârlık kategorilerinin, Türk kültüründe işlerlik gösterip göstermediği saptanacaktır. Fedakârlık davranışlarındaki cinsiyete dayalı benzerlik ve farklılıkların incelenmesi ise alanyazının genişlemesine katkıda bulunacaktır. Araştırma ikinci olarak, fedakârlık davranışlarından alınan doyum ile özgecil aşk arasındaki ilişkiyi ve bu ilişkide acının dönüştürücü gücünün arac1 rolünü incelemeyi amaçlamaktadır. $\mathrm{Bu}$ amaçla "Özgecil aşk, acının dönüştürücü gücü ve fedakârlık doyumu arasında istatistiksel olarak anlamlı bir ilişki var mıdır?” ve "Özgecil aşk doğrudan ve acının dönüştürücü gücü aracılı̆̆ıyla dolaylı olarak fedakârlık doyumunu yordamakta mıdır?" sorularına cevap aranmaktadır. Böylece fedakârlık alanyazınının daha önce çalışmamış bir yönüne odaklanılmaktadır.

\section{Yöntem}

\subsection{Araştırma Modeli}

$\mathrm{Bu}$ çalışma, karma araştırma yöntemlerinden biri olan ve "nitel ve nicel verileri eş zamanlı toplayıp birleştiren" yakınsak paralel desende yapılandırılmıştır. Yakınsak paralel desen "veri türlerinden birinin güçlü yanlarını kullanarak diğer veri türünün zayıf yönlerini dengelemeyi", başka bir deyişle nicel ve nitel yöntemin güçlü yanlarını birleştirmeyi ve araştırma problemine dair "daha bütünlüklü bir anlayış geliştirmeyi” amaçlamaktadır (Creswell, 2017, s. 704-705). Bu doğrultuda çalışma iki ayrı fakat birbirini tamamlayan amaca yönelik olarak yürütülmüştür. İlk amaç, evlilik ilişkisinde ne tür fedakârlık davranışları sergilendiğini ve bu davranışların cinsiyete göre farklılık gösterip göstermediğini keşfetmektir. Belirtilen amaç doğrultusunda katılımcılardan "Evlilik ilişkinizde sergilediğiniz üç fedakârlık davranışını yazınız.” sorusunu (yönergesini) cevaplamaları istenmiştir. $\mathrm{Bu}$ soru evli bireylerin kişisel fedakârlık yaşantılarını ortaya koymayı amaçladığından çalışmanın nitel ayağını oluşturmaktadır. Çalışmanın ikinci amacı özgecil aşk, acının dönüştürücü gücü ve fedakârlık doyumu arasındaki ilişkileri ve özgecil aşkın acının dönüştürücü gücü aracılığıyla fedakârlık doyumunu yordayıp yordamadığını incelemektir. Bu amaç doğrultusunda çalışmanın nicel ayağı yordayıcı ilişsisel araştırma deseninde yapılandırılmıştır. Yordayıcı desenler, araştırmacıların sadece değişkenler arasındaki ilişkileri belirlemekle yetinmediği, ayrıca hangi değişkenin ya da değişkenlerin diğerini yordayacağına dair öngörüde bulunduğu araştırma desenlerini betimlemektedir (Creswell, 2017).

\subsection{Araştırma Grubu}

Güçlü bir ilişkisel paylaşımın prototipik bir örneğini temsil ettiği (Clark ve Mills, 1979) düşünüldüğünden araştırmaya yalnızca evli bireyler dâhil edilmiştir. $\mathrm{Bu}$ bireylerin seçiminde genel popülasyona ulaşmak -böylece çalışmaya toplumun tipik bir örneğini dâhil etmek- hedeflendiği için çevrimiçi veri toplama tekniklerinden faydalanılmıştır. Çalışmanın örneklemini 198'i kadın (\% 62.3), 120'si erkek (\% 37.7) olmak üzere toplam 318 evli birey oluşturmaktadır $(\bar{x}=38.36, S s=9.79)$. Katılımcıların yaş aralığı 21-68, yaş ortalamas1 38.36'dır $(S s=9.79)$. Örneklemin büyük bir bölümü $(N=307, \% 96.5)$ ilk evliliğini yaşamaktadır. Katılımciların evlilik süreleri 1 ile 43 yıl arasında değişmekte olup ortalama evlilik süresi 12.43'tür ( $S s=$ 10.45).

\subsection{Veri Toplama Araçları}

$\mathrm{Bu}$ araştırmada veriler Kişisel Bilgi Formu, Fedakârlık Doyum Ölçeği, Aşka İlişkin Tutumlar Ölçeği (Kısa Form) ve Acının Dönüştürücü Gücü Ölçeği aracılığıyla toplanmıştır. Kullanılan ölçme araçlarının özellikleri aşağıda sunulmuştur.

Kişisel Bilgi Formu. Bu form, katılımcıların yaş, cinsiyet, evlilik sayısı ve evlilik süresi gibi konularda genel karakteristiklerini belirleyebilmek için araştırmacılar tarafından hazırlanmıştır. Formda ayrıca katılımcılardan evlilik ilişkilerinde sergiledikleri üç fedakârlık davranışını yazmaları istenmiştir. 
Fedakârlık Doyum Ölçeği. Kişinin yaptığı fedakârlıktan sağladiğı doyumu ölçmek amaciyla geliştirilmiş olan Fedakârlık Doyum Ölçeği (Whitton vd., 2007), 6 maddeden (örneğin, "Eşim için bir şeylerden vazgeçmek kişisel doyum sağlar") oluşan 7'li Likert tipi ( 1 = Kesinlikle katılmıyorum, 7 = Kesinlikle katılıyorum) bir ölçme aracıdır. Ölçeğin üç maddesi ters yönde puanlanmaktadır. Ölçekten alınabilecek puanlar 6 ile 42 arasında değişmekte olup alınan yüksek puanlar, yapılan fedakârlıktan sağlanan doyumun fazla olduğuna işaret etmektedir. Ölçeğin Türk kültürüne uyarlaması Topcu ve Tezer (2013) tarafından yapılmış ve Cronbach alpha iç tutarlılık katsayısı .74 olarak bulunmuştur. Şimdiki çalışmada ölçeğin Cronbach alpha değeri .67 olarak hesaplanmıştır.

Aşka İlişkin Tutumlar Ölçeği (Kısa Form). Kişinin romantik ilişkilerdeki aşk tarzlarını belirlemek üzere geliştirilen ve 6 alt boyuttan (eros, storge, ludus, mania, pragma ve agape) oluşan bir tutum ölçeğidir. Bu ölçek, 42 maddeden oluşan Aşka İlişkin Tutumlar Ölçeği'nin (Hendrick ve Hendrick, 1986) 24 maddeden oluşan kısa formudur (Hendrick, Hendrick ve Dicke, 1998). Ölçek 5'li Likert tipi bir derecelendirmeye sahip olup her alt boyuttan alınabilecek puan 4 ile 20 arasında değişmektedir. Alınan yüksek puanlar, ölçülen aşk tarzına ilişkin tutumların daha baskın olduğuna işaret etmektedir. Şimdiki çalışmada ölçeğin yalnızca özgecil aşk alt boyutu kullanılmıştır. Orijinal ölçeğin alt boyutlarına ait Cronbach alpha katsayıları .68 ile .85 arasında değişmektedir. Özgecil aşk alt boyutunun iç tutarlılık katsayısı .85'tir. Ölçeğin Türk kültürüne uyarlaması Büyükşahin ve Hovardaoğlu (2004) tarafindan yapılmıştır. İlişkisi olan bireylerde özgecil aşk için saptanan Cronbach alpha iç tutarlılık katsayısı değerinin .80 olduğu görülmüştür. Şimdiki çalışmada ise ölçeğin Cronbach alpha değeri .86 olarak hesaplanmıştır.

Acının Dönüştürücü Gücü Ölçeği. Kişinin zorlayıcı ve 1stırap verici yaşam olaylarının ardından pozitif yönde değişimler deneyimlenebileceğine ilişkin inançlarını ölçmek üzere geliştirilmiş olan bir ölçme aracıdır (Joshanloo, 2014). 7'li Likert tipi bir derecelendirme üzerinden puanlanan ölçek, tek boyuttan ve beş maddeden oluşmaktadır. Ölçekten alınabilecek puanlar 5 ile 35 arasında değişmekte olup yüksek puanlar, acının pozitif yönde dönüştürücü bir güce sahip olduğu yönündeki inançların yüksek olduğuna işaret etmektedir. Joshanloo (2014, 2015) tarafından yapılan çalışmalarda ölçeğin Cronbach alpha iç tutarlılık katsayısının .66 ile .75 arasında değiştiği görülmüştür. Dinçer ve diğerleri (2015) tarafindan yapılan Türk kültürüne uyarlama çalışmasında ölçeğin Cronbach alpha iç tutarlılık katsayısı .84 olarak hesaplanmıştır. Ölçeğin şimdiki çalışma kapsamında saptanan Cronbach alpha değeri ise .87'dir.

\section{4. İşlem}

Araştırmada kullanılan ölçme araçları çevrimiçi anket sitesine yüklenmiş ve çevrimiçi form haline getirilmiştir. Veriler, bu linkin çeşitli sosyal medya platformlarında paylaşılması yoluyla internet üzerinden toplanmıştır. $\mathrm{Bu}$ şekilde hem katılımcıların gizliliği korunmuş hem de onlara kendi belirledikleri ve uygun oldukları bir zamanda çalışmaya katılma imkânı sunulmuştur. Katılımcılara, araştırmaya dair bilgi vermek ve gönüllü katılımlarını belgelemek için uygulamanın hemen öncesinde bir çevrimiçi bilgilendirilmiş onam formu sunulmuştur. Yalnızca bu formu onaylayan katılımcılar çalışmaya katılabilmiştir. Hazırlanan formlar, ilerlemek için her bir soruya cevap vermeyi gerektiren bir formatta yapılandırıldığından boş bırakılan madde olmamıştır.

\subsection{Verilerin Analizi}

Veri toplama setinde öncelikle fedakârlık davranışlarını tanımlamaya ve sıklıklarını tespit etmeye yönelik sorular sorulmuştur. Tanımlanan fedakârlık davranışlarının sayısal verilere dönüştürülmesinde betimsel analiz tekniği kullanılmıştır. Yazılı ifadelerdeki ortak temalara ulaşmak için Creswell'in (2017: 314-315) belirttiği aşamalar takip edilmiştir: (1) Öncelikle varolan nitel verilerin keşfedici ilk analizi yapılmıştır. (2) Ardından "verilerden anlam çıkarmak, onları metin veya görsel parçalara ayırmak, bu parçaları kodlarla etiketlemek, kodlamaların çakışıp çakışmadığını ya da gereksiz yere kullanılıp kullanılmadığını incelemek ve bu kodları geniş temalarla daraltmak" için tümevarımsal bir süreç izlenmiştir. (3) Hazırlanmış olan kodlama listesi iki araştırmacı tarafından ayrı ayrı kontrol edilip yeniden incelenmiştir. $\mathrm{Bu}$ gözden geçirmeler karşılıklı olarak yeniden değerlendirilmiş ve tablolaştırılmıştır. (4) Son olarak kod listesi kapsayıcı temalar etrafında daraltılmış ve cinsiyete göre tablolaştırılmıştır.

Araştırmanın ikinci kısmında SPSS 22.0 paket programı kullanılmıştır. Özgecil aşk, acının dönüştürücü gücü ve fedakârlık doyumu arasındaki ilişkiler Pearson Çarpım Moment Korelasyon Katsayısı kullanılarak analiz edilmiştir. Değişkenler arasındaki ilişki örüntülerini incelemek amacıyla [yani fedakârlıktan alınan doyumun özgecil aşk ve acının dönüştürücü gücü tarafindan nasıl açıklandığını açığa çıkarmak için] regresyon analizi yapılmıştır. Acının dönüştürücü gücünün aracı rolü ise Sobel testi kullanılarak incelenmiştir.

\section{Bulgular}

\subsection{Fedakârlık Davranışlarına Ait Bulgular}

Araştırmanın ilk amacı doğrultusunda katılımcıların fedakârlık olarak tanımladıkları davranışlar, betimsel analiz tekniği kullanılarak incelenmiş ve cinsiyete göre sınıflandırılmıştır. Kadın ve erkeklerin fedakârlık davranışlarını temsil eden betimsel bilgiler (frekans dağılımları) Tablo 1'de sunulmuştur (Fedakârlık alanlarına ilişkin sayısal verilerin sunumunda, kadınların toplam sayısı için $n_{K}$, erkeklerin toplam sayısını belirtirken $n_{E}$ kısaltmaları kullanılmıştır).

Tablo 1'de görülen on bir gündelik fedakârlık alanının dokuzunda [günlük işler için $n_{K}=81, n_{E}=19$, iletişim ve etkileşim için $n_{K}=90, n_{E}=38$, aile için $n_{K}=69, n_{E}=11$, para ve hediyeler için $n_{K}=44, n_{E}=9$, sağlık, yaşam tarzı ve gelecek planları için $n_{K}=22, n_{E}=8$, okul ve iş için $n_{K}=20$, $n_{E}=4$, görünüm için $n_{K}=5, n_{E}=$ belirtilmemiş, fiziksel ve cinsel yakınlık için $n_{K}=1, n_{E}=$ belirtilmemiş] kadınların erkeklerden fazla fedakârlık bildiriminde bulunduğu, erkeklerin ise yalnızca eğlence ve boş zaman etkinlikleri $\left(n_{K}\right.$ $\left.=3, n_{E}=14\right)$ ve diğer cinsle ilişkiler konularında $\left(n_{K}=\right.$ belirtilmemiş, $n_{E}=1$ ) kadınlardan daha fazla fedakârlık bildiriminde bulunduğu görülmüştür. Eşin aile içindeki sorumluluklarını üstlenme, işte ve evde çifte mesai yapma, 
eşin ailesiyle birlikte yaşama, görünümünde değişiklik yapma, ortak zamandan ve cinsel yaşamdan feragat etme gibi fedakârlık davranışlarının yalnızca kadınlar tarafindan gündeme getirildiği gözlenmiştir. Benzer şekilde eşin kararlarına itaat etme ve uyum gösterme davranışlarının da çoğunlukla kadınlar tarafından bildirildiği saptanmıştır. Karşı cinsle ilgilenmeme konusundaki fedakârlık davranışını ise yalnızca bir erkek katılımcı bildirmiştir. Son olarak gündelik fedakârlık alanlarında olduğu gibi büyük fedakârlık alanlarında da (yerleşim yeri ve iş değişikliği, iş hayatına da ya da eğitim hayatına son/ara verme) kadınların erkeklerden daha fazla fedakârlık davranışı bildiriminde bulunduğu saptanmıştır $\left(n_{K}=71, n_{E}=34\right)$. Bu fedakârlık davranışları arasında iş hayatını sonlandırma eylemini yalnızca kadınlar belirtmiştir.

Tablo 1: Kadın ve Erkeğe Ait Fedakârlık Alanları ve Frekans Dağılımları

\begin{tabular}{|c|c|c|c|}
\hline Fedakârlık Alanları & & $\begin{array}{c}\text { Kadın } \\
\mathbf{f}\end{array}$ & $\begin{array}{c}\text { Erkek } \\
\text { f }\end{array}$ \\
\hline \multicolumn{4}{|c|}{ Gündelik Fedakârlıklar } \\
\hline Günlük işler & $\begin{array}{l}\text { Ev işleri/küçük iyilikler } \\
\text { Çocuk bakımı } \\
\text { Eşin aile içindeki tüm sorumluluklarını üstlenme* } \\
\text { Çifte mesai (hem işte hem evde)* }\end{array}$ & 81 & 19 \\
\hline İletişim ve etkileşim & $\begin{array}{l}\text { Tartışmalarda alttan alma } \\
\text { Ortak zamandan feragat* } \\
\text { Kendi istek ve ihtiyaçlarından feragat etme ya da onları erteleme } \\
\text { Eşin istek ve ihtiyaçlarına öncelik verme } \\
\text { Eşin olumsuz davranışlarına katlanma } \\
\text { Eşin kararlarına itaat ve uyum gösterme } \\
\text { Kendi olumsuz davranışlarını azaltma }\end{array}$ & 90 & 38 \\
\hline Aile & $\begin{array}{l}\text { Kendi ailesiyle ilişkilerinden feragat etme } \\
\text { Eşin ailesine ve onların olumsuz davranışlarına katlanma } \\
\text { Eşin ailesiyle birlikte yaşama* }\end{array}$ & 69 & 11 \\
\hline Para ve hediyeler & Maddi fedakârlık, kişisel alışverişten feragat & 44 & 9 \\
\hline $\begin{array}{l}\text { Sağlık, yaşam tarzı ve gelecek } \\
\text { planları }\end{array}$ & $\begin{array}{l}\text { Yaşam tarzı değişikliği } \\
\text { Gelecek planlarını erteleme (örn., çocuk) } \\
\text { Özgürlüklerini sınırlandırma } \\
\text { Sağlık problemlerinde yanında olma }\end{array}$ & 22 & 8 \\
\hline Okul ve iş & İş ya da eğitim hayatında eşine destek olma & 20 & 4 \\
\hline Eğlence ve boş zaman etkinlikleri & Hobilerinden vazgeçme & 3 & 14 \\
\hline Görünüm & Görünüm değişikliği* & 5 & - \\
\hline Fiziksel ve cinsel yakınlık & Cinsel yaşamdan feragat* & 1 & - \\
\hline Diğer cinsle ilişkiler & Karşı cinsle ilgilenmemek ${ }^{* *}$ & - & 1 \\
\hline \multicolumn{4}{|c|}{ Büyük Fedakârlıklar } \\
\hline Kritik değişiklikler & $\begin{array}{l}\text { Yerleşim yeri değişikliği (şehir ya da ülke) } \\
\text { İş ve kariyer değişikliği } \\
\text { İş hayatını sonlandırma* } \\
\text { Eğitim hayatına ara ya da son verme }\end{array}$ & 71 & 34 \\
\hline
\end{tabular}

* İşaretli alanlar yalnızca kadın katılımcılar tarafından bildirilmiştir.

**İşaretli alanlar yalnızca erkek katılımcılar tarafından bildirilmiştir.

\subsection{Fedakârlık Doyumu, Özgecil Aşk ve Acının Dönüştürücü Gücüne İlişkin Bulgular}

Çalışmanın ikinci amacı evlilik ilişkisinde sergilenen fedakârlık davranışlarından alınan doyum ile özgecil aşk arasındaki ilişkiyi ve bu ilişkide spritüel bir güç olarak acının dönüştürücü gücünün aracı etkisini incelemektir. Bu amaçla çalışmada istatistiksel analizler yapılmış ve öncelikle, özgecil aşk ve acının dönüştürücü gücünün fedakârlık doyumu ile ilişkili olup olmadığını ortaya koymak amacıyla Pearson Momentler Çarpımı Korelasyon Katsayısı tekniği uygulanmıştır. Tablo 2'de hem değişkenler arası ilişkiler hem de değişkenlere ait ortalama ve standart sapmalar sunulmuştur.

Tablo 2'de görüldüğü gibi, evlilikte sergilenen fedakârlık davranışından alınan doyum ile özgecil aşk $(r=.48, p<.01)$ ve acının dönüştürücü gücü $(r=.28, p<.01)$ arasında pozitif yönde anlamlı bir ilişki vardır. Özgecil aşk ve acının dönüştürücü gücü $(r=.37, p<.01)$ arasında da orta düzeyde pozitif yönde anlamlı bir ilişki bulunmaktadır. 
Tablo 2: Fedakârlık Doyumu, Özgecil Aşk ve Acının Dönüştürücü Gücü Arasındaki İlişkiler

\begin{tabular}{lccc}
\hline Değişkenler & 1 & 2 & 3 \\
\hline Fedakârlık doyumu (1) & 1.00 & & \\
Özgecil aşk (2) & $.48^{* *}$ & 1.00 & \\
Acının dönüştürücü gücü (3) & $.28^{* *}$ & $.37^{* *}$ & 1.00 \\
\hline$\overline{\mathrm{x}}$ & 4.32 & 2.99 & 4.45 \\
$\mathrm{SD}$ & 1.20 & 1.13 & 1.60 \\
\hline
\end{tabular}

$* * p<.01$

Özgecil aşk ve fedakârlık doyumu arasındaki ilişkinin açıklanmasında acının dönüştürücü gücünün rolü Baron ve

Tablo 3: Özgecil Aşk ile Fedakârlık Doyumu Arasındaki İlişkide Acının Dönüştürücü Gücünün Aracılık Etkisinin İncelenmesine İlişkin Regresyon Analiz Sonuçları
Kenny (1986) tarafından öne sürülen üç koşul doğrultusunda incelenmiştir. Buna göre;

Model 1: Özgecil aşk ile acının dönüştürücü gücü arasında doğrudan ilişki,

Model 2: Özgecil aşk ile fedakârlık doyumu arasında doğrudan ilişki,

Model 3: Acının dönüştürücü gücü ve fedakârlık doyumu arasında doğrudan ilişki,

Model 4: Özgecil aşk ve fedakârlık doyumu arasında acının dönüştürücü gücünün aracılığıyla dolaylı bir ilişkinin olduğu öngörülmüştür.

\begin{tabular}{|c|c|c|c|c|c|}
\hline Aracı Değişken Test Adımları & B & $\beta$ & sh & $t$ & $p$ \\
\hline \multicolumn{6}{|l|}{ Model 1} \\
\hline Özgecil aşk -> Acının dönüştürücü gücü & .52 & .37 & .23 & 12.195 & $.00 * *$ \\
\hline \multicolumn{6}{|l|}{$R=.37, R^{2}=.13, F=49.987$} \\
\hline \multicolumn{6}{|l|}{ Model 2} \\
\hline Özgecil aşk -> Fedakârlık doyumu & .50 & .47 & .16 & 16.791 & $.00 * *$ \\
\hline \multicolumn{6}{|l|}{$R=.47, R^{2}=.22, F=93.662$} \\
\hline \multicolumn{6}{|l|}{ Model 3} \\
\hline $\begin{array}{l}\text { Acının dönüştürücü gücü -> Fedakârlık doyumu } \\
R=.27, R^{2}=.07, F=26.391\end{array}$ & .20 & .27 & .19 & 17.782 & $.00 * *$ \\
\hline \multicolumn{6}{|l|}{ Model 4} \\
\hline Özgecil aşk -> Fedakârlık doyumu & .46 & .43 & .03 & 8.231 & $.00 * *$ \\
\hline Acının dönüştürücü gücü -> Fedakârlık doyumu & .08 & .11 & .05 & 2.212 & $.02 *$ \\
\hline$R=.49, R^{2}=.24, F=49.854$ & & & & & \\
\hline
\end{tabular}

Önerilen her bir modelin $\operatorname{Beta}(\beta)$ ve anlamlılığ değerlendirilerek acının dönüştürücü gücünün özgecil aşk ve fedakârlık doyumu arasındaki ilişkideki aracılık rolü (tam aracı ya da kısmi aracılık) Sobel testi ile incelenmiştir. Elde edilen bulgular Tablo 3'te sunulmuştur.

Tablo 3 'te acının dönüştürücü gücü modele girdikten sonra özgecil aşkın, fedakârlık doyumunu açıklama düzeyinin azalması fakat anlamlı olması, acının dönüştürücü gücünün bu ilişkide kısmi aracı bir değişken olduğunu göstermektedir. Sobel testinin sonuçlarında $\mathrm{z}$ değeri 2.17 ( $p$ $<.05$ ) olarak bulunmuştur. Bu bulgulara göre özgecil aşkın hem doğrudan hem de acının dönüştürücü gücü aracılığıyla dolaylı olarak fedakârlık doyumu üzerinde anlamlı bir etkisi vardır (Bkz. Şekil 1).

\section{Tartışma ve Sonuç}

$\mathrm{Bu}$ çalışma iki farklı fakat birbirini tamamlayıcı amaca yönelik olarak yürütülmüştür. İlk amaç, evlilik ilişkisinde ne tür fedakârlık davranışları sergilendiğini ve bu davranışların cinsiyete göre farklılık gösterip göstermediğini keşfetmektir. İkinci amaç özgecil aşk, acının dönüştürücü gücü ve fedakârlık doyumu arasındaki ilişkileri ve özgecil aşkın acının dönüştürücü gücü aracılığıyla fedakârlık doyumunu yordayıp yordamadığını incelemektir.

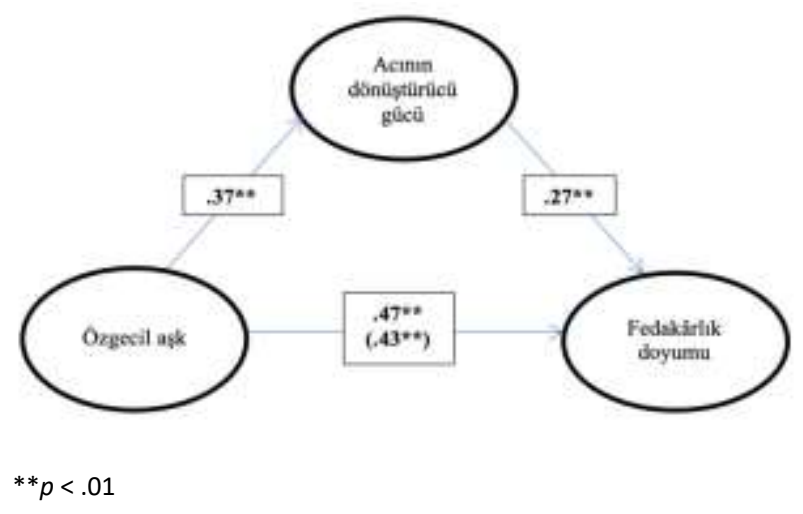

Şekil 1: Özgecil Aşk ve Fedakârlık Doyumu Arasındaki İlişkide Acının Dönüştürücü Gücünün Aracı Rolü 


\subsection{Fedakârlık Davranışları ve Cinsiyet Olgusu}

Araştırma sonuçları, kadın ve erkeklerin hem gündelik yaşamda hem de önemli ve büyük meselelerde sik sik fedakârlık davranışı sergilediğini ortaya koymuştur. Katılımcıların fedakârlık davranışlarının Impett ve diğerleri (2005) tarafından öne sürülen iki ana fedakârlık alanında toplandığı görülmektedir: Gündelik fedakârlıklar ve büyük fedakârlıklar. Gündelik fedakârlıklar alanı günlük işler, iletişim ve etkileşim, aile, para ve hediye, sağlık, yaşam tarzı ve gelecek planları, okul ve iş, eğlence ve boş zaman etkinlikleri, görünüm, fiziksel ve cinsel yakınlık, diğer cinsle ilişkiler alt kategorilerinden; büyük fedakârlıklar alanı ise iş ve yerleşim yeri değişiklikleri, iş hayatına ya da eğitim hayatına son/ara verme alt kategorilerinden oluşmaktadır.

Araştırma sonuçları, kadın ve erkeklerin en fazla iletişim ve etkileşim, günlük işler, aile, para ve hediyeler konusunda fedakârlık yaptığını göstermektedir. Bunları sırasıyla sağlık, yaşam tarzı ve gelecek planlarının, okul ve işle ilgili konuların, eğlence ve boş zaman etkinliklerinin, görünüm değişikliklerinin, fiziksel ve cinsel yakınlık ve son olarak diğer cinsle ilişkilerin takip ettiği gözlenmektedir. Fakat bu fedakârlık alanları cinsiyete göre sıralandığında bazı farklılıklar dikkat çekmektedir. Fedakârlık dağılımları kadınlar için şu şekilde bir sıralama izlemektedir: İletişim ve etkileşim $>$ günlük işler $>$ aile $>$ para ve hediyeler $>$ sağlık, yaşam tarzı ve gelecek planları $>$ okul ve işle ilgili konular $>$ görünüm $>$ eğlence ve boş zaman etkinlikleri $>$ fiziksel ve cinsel yakınlık. Diğer cinsle ilişkiler konusunda kadınların herhangi bir fedakârlık bildiriminde bulunmadığı görülmektedir. Erkekler için ise dağılım iletişim ve etkileşim $>$ günlük işler $>$ eğlence ve boş zaman etkinlikleri $>$ aile $>$ para ve hediyeler $>$ sağlık, yaşam tarzı ve gelecek planları $>$ okul ve işle ilgili konular $>$ diğer cinsle ilişkiler şeklinde siralanmaktadir.

İletişim ve etkileşim kategorisi tartışmalarda alttan alma; ortak zamandan, kendi istek ve ihtiyaçlarından feragat etme ya da onları erteleme; eşin istek ve ihtiyaçlarına öncelik verme ve olumsuz davranışlarına katlanma; eşin kararlarına itaat etme ve uyum gösterme ve kendi olumsuz davranışlarını azaltma konularını kapsamaktadır. $\mathrm{Bu}$ kategoride genel olarak kadınların erkeklerden daha fazla fedakârlık bildiriminde bulunduğu görülmektedir. Özellikle ortak zamandan feragat etme konusunda yalnızca kadınların bildirimde bulunduğu gözlenmektedir. Sosyo-kültürel kuram bu farklılıkları kadın ve erkeklerin gündelik yaşamdaki davranışlarına yansıyan statü ve güç olguları (Eagly ve Wood, 1999; Wood ve Eagly, 2002); SakallıUğurlu ve Türkoğlu (2017) toplumsal cinsiyet ile ilgili kalıpyargılar; Gilligan (2017) ise bakım etiğine dayalı ahlaki kaygılar üzerinden açıklamaktadır. Bununla birlikte Ewart, Taylor, Kraemer ve Agras (1991) eşinin olumsuz davranışlarını tolere etme çabalarının evlilikte pozitif bir ilişki iklimi yaratma gayretinin bir ürünü olarak da değerlendirilebileceğini öne sürmektedir.

Günlük işler kategorisi ev işleri, çocuk bakımı, eşin aile içi sorumluluklarını üstlenme ve çifte mesai konularından oluşmaktadır. $\mathrm{Bu}$ kategoride genel olarak kadınların erkeklerden daha fazla fedakârlık bildiriminde bulunduğu görülmektedir. Özellikle eşin aile içindeki sorumluluklarını üstlenme ve çifte mesai konularının yalnızca kadınlar tarafindan bildirildiği gözlenmektedir. $\mathrm{Bu}$ bulgular alanyazınla tutarlıdır. Sakallı-Uğurlu ve Türkoğlu (2017) tarafından yapılan bir araştırma, Türk toplumunda evli kadınların "fedakâr, anaç, ev hanımı ve sorumluluk sahibi"; evli erkeklerin ise "sorumluluk sahibi, otoriter, baba, aile reisi ve korumacı" olarak algılandığını ortaya koyarak şimdiki araştırmanın bulgularını desteklemektedir.

Aile kategorisi kendi ailesiyle ilişkilerinden feragat etme, eşin ailesiyle birlikte yaşama ve onların olumsuz davranışlarına katlanma konularını kapsamaktadır. Bu kategoride genel olarak kadınların erkeklerden daha fazla fedakârlık bildiriminde bulunduğu görülmektedir. Temanın içerdiği bazı fedakârlık davranışları Impett ve diğerlerinin (2005) tespit ettiği davranışlardan farklılık göstermektedir. Örneğin kadın katılımcıların bildirdiği fedakârlık davranışları arasında "eşin ailesiyle birlikte yaşama" gibi kültüre özgü bir bulgu vardır. Türk toplumu kültürel açıdan toplulukçu bir yapıya sahip olduğundan erkek eşin ailesiyle aynı evde yaşama sosyal yaşamda sıkça rastlanan durumlardan biridir. Toplulukçu kültürlerde bireylerin geniş aileye uyum sağlaması önemlidir (Triandis, 1993) ve geleneksel toplum yapısı bu uyumu en çok kadınların göstermesini beklemektedir. Şimdiki araştırma bulgularında kadınların eşleri ve evlilikleri için kendi ailelerini karşılarına almaları, onlarla eşin isteği doğrultusunda daha az görüşmeye başlamaları ya da bayram ve tatil zamanlarını kendi ailelerinin değil eşlerinin ailesinin yanında geçirmeleri yine kadınların sıkça sergilediği fedakârlık davranışları arasındadır.

Para ve hediyeler kategorisi maddi fedakârlıkları ve kişisel alışverişten feragati içermektedir. $\mathrm{Bu}$ alanda kadınların erkeklerden daha fazla fedakârlık bildiriminde bulunduğu görülmektedir. Betimsel analizler kadınların özellikle kendine özel alışverişlerini sınırlandırma, şahsi ihtiyaçlarını karşılamayı erteleme, ziynet eşyalarını iş hayatını düzene sokması için eşe verme gibi maddi konularda sik sık fedakârlık davranışı sergileyerek eşin ev idaresine katkıda bulunduğunu ortaya koymaktadır. Alanyazında yer alan Ben Tasavvuruna Ötekini Katma Modeli de yakın ilişkilerde eşlerin finansal kaynak paylaşımı yoluyla birbirinin benliğini genişlettiğini öne sürmektedir (Aron, Aron ve Smollan, 1992; Aron, Mashek ve Aron, 2004). Şimdiki çalışma eşler arasındaki finansal kaynak paylaşımının maddi fedakârlık davranışlarıyla da ortaya çıkabileceğini göstermesi bakımından dikkate değerdir.

Sağlık, yaşam tarzı ve gelecek planları kategorisi yaşam tarzı değişikliği, gelecek planlarını erteleme, özgürlüklerini sınırlandırma ve sağlık problemlerinde eşin yanında olma konularını içermektedir. Bu kategoride daha çok kadınların bildirimde bulunduğu görülmektedir. Gilligan'ın (2017) psiko-sosyal gelişim perspektifinden bakıldığında kadınların özgürlüklerini sınırlandırma ve sağlık problemlerinde eşinin yanında olma konularında bildirdiği fedakârlık davranışlarının (onların başkalarına bakım verme sorumluluğu ile kendilerine karşı sorumlulukları arasında kaldığında) yaptıkları ilişkisel seçimler ve yaşadıkları ikilemler ile alakalı olduğu düşünülmektedir. Okul ve işle ilgili konular kategorisi kapsamında rapor edilen iş ya da eğitim hayatında eşe destek olma yönündeki fedakârlık davranışlarının da benzer ilişkisel seçimler ve bakım sorumluluğuyla ilgili olduğu düşünülmektedir.

Eğlence ve boş zaman etkinlikleri kategorisi hobilerden vazgeçmeyi içermekte ve daha çok erkeklerin bildirimde bulunduğu bir alanı temsil etmektedir. Betimsel analizler 
erkeklerin evlendikten sonra futbol, arkadaş toplantıları ve akşam gezmeleri gibi kişisel hobilerini daha seyrek gerçekleştirebildiğini göstermektedir. $\mathrm{Bu}$ bulgular alanyazınla tutarlıdır. Örneğin Sakallı-Uğurlu ve Türkoğlu (2017) tarafından yapılan çalışmada bekâr erkeklerin öncelikli olarak “özgür” ve "serbest” olma, evli erkeklerinse "sorumluluk sahibi" ve "aile reisi” olma özellikleriyle ön plana çıktığını ortaya koymaktadır. Şimdiki araştırma bulguları da erkeklerin evlendikten sonra bireysel özgürlüklerinden görece feragat ettiğine işaret etmektedir.

Görünüm değişikliği, eşin isteklerine ve değerlerine bağl1 olarak fiziksel görünüşte değişiklik yapma konularını içermekte ve yalnızca kadınların bildirimde bulunduğu bir fedakârlık alanını temsil etmektedir. Bu değişiklikler eşin istekleri doğrultusunda, dişarıya çıkarken dekolte giyinmeme ya da başörtüsü kullanma gibi feminenliği gizleme davranışları olarak ortaya çıkabileceği gibi ev içinde ince çorap giyme gibi özel alanda daha feminen olma davranışları olarak da görülebilmektedir. Çalışma grubundaki fedakârlık bildirimlerinin yalnızca kadın bedeni üzerinden olması, toplumsal cinsiyet perspektifinden bakıldığında kadın bedenine yüklenen sosyal, kültürel ve politik anlamlarla ilgili olabilir. Zira geleneksel toplum yapısında kadın bedeni genellikle namusla ilişkilendirilerek erkeğin gözünden ve sosyal bir beden olarak konumlandırılabilmektedir (Bilgin, 2016).

Son olarak gündelik fedakârlık alanlarında olduğu gibi büyük fedakârlık alanında da (iş ve yerleşim yeri değişikliği, iş hayatını da ya da eğitim hayatını sonlandırma) kadınların erkeklerden daha fazla fedakârlık davranışı bildiriminde bulunduğu görülmektedir. $\mathrm{Bu}$ fedakârlık davranışları arasında özellikle iş hayatını sonlandırma eyleminin yalnızca kadınlar tarafından belirtilmiş olması dikkat çekicidir ve ataerkil toplum yapısında kadının kamusal alandan, iş hayatından uzaklaştığı ve özel alanla kısıtlandığı yönündeki feminist eleştirileri destekler niteliktedir (Günindi-Ersöz, 2015).

Yukarıda bahsi geçen fedakârlık davranışları ve alanları göz önünde bulundurulduğunda, çoğunun eşin ve ilişkinin iyi oluşunu sürdürmeye dönük yaklaşma motivasyonlu davranışlar olduğu anlaşılmaktadır. Buna göre çalışma grubunun temsil ettiği ilişkisel ve kültürel dinamiklerin kadın ve erkekleri -kimi zaman birbirinden farklı alanlarda olsa da- fedakârlıkta bulunmaya teşvik eden bir yapıda olduğu söylenebilir.

\subsection{Fedakârlık Doyumu, Özgecil Așk ve Acının Dönüştürücü Gücü Arasındaki İlişkiler}

Şimdiki araştırma, ilk kısımdaki fedakârlık davranışlarını, onların sıklık dağılımlarını ve alanlarını ortaya koyan ön bulguların ötesine geçerek fedakârlık doyumunun arkasında yatan farklı dinamiklere de açıklık kazandırmayı amaçlamıştır. Bu bağlamda çalışmada, acının dönüştürücü gücü ve özgecil aşkın fedakârlıktan alınan doyumla ilişkili olduğu ve özgecil aşkın hem doğrudan hem de acının dönüştürücü gücü aracılığıyla dolaylı olarak fedakârlık doyumunu yordadığı saptanmıştır. Böylelikle özgecil aşk ve acının dönüştürücü gücüyle ilgili inançların fedakârlık doyumunun altında yatan iki içsel kaynak olduğu ortaya çıkmıştır.
Evlilikler, Erikson'ın (1982/2014) psikososyal gelişim kuramında açıkladığı gibi, "yakınlığa karşı yalıtılmışlık" evresinin başarılması gereken temel gelişimsel görevlerinden biri olan yakınlık duygusunun kurulması ve sürdürülmesine dayalıdır. $\mathrm{Bu}$ evrede evlilik ilişkisi içinde olan bireyler, Gilligan'ın (2017) bakım etiği kavramında temas ettiği gibi, kendisi için önemli olan bir diğer insana, yani eşine özen gösterme, onun ihtiyaçlarına duyarlı olma ve beklentilerini karşılama gibi yakın ilişki görevlerini gerçekleştirmektedir. Özgecil aşk tarzının beraberinde getirdiği eşin ihtiyaçlarına karşı duyarlı olma ve bu ihtiyaçları karşılaşmayı kutsal bir görev sayma eğiliminin (Lee, 1977), bu evrenin gelişimsel, duygusal ve sosyal görevleriyle bütünleşerek fedakârlık doyumunun önemli bir yordayıcısı haline geldiği düşünülmektedir. Hatta bu durumun, Kelley ve Thibault (1978) tarafindan belirtildiği gibi, sağlıklı ve güçlü bir romantik ilişkinin (evlilik ilişkisinin) temel bileşenlerinden biri olduğu öngörülmektedir. Partnerler evlilik ilişkisine duygusal, sosyal, finansal, entelektüel vb. tüm kaynakları ile dahil olmakta ve ilişkileri sırasında bu kaynakları birbirlerinin kullanımına açmaktadır (Aron vd., 2004; Dinçer, 2017; Dinçer, Ekşi ve Aron, 2018). Özgecil aşk tarzı, kişinin kendinin olan ne varsa hepsini partnerinin erişimine açtığı bu tür bir aşk ilişkisini imlemektedir (Hendrick ve Hendrick, 1986). Böyle bir yakın ilişki zemininde partnerlerin benlik sınırları esnemekte, genişlemekte; böylece yeni bir ortak kimlik deneyimlenmektedir (Aron vd., 2004; Dinçer, 2017; Kelley, 1991). Bu birlikte büyüme zemininin, fedakârlıktan alınan doyumu pekiştirdiği düşünülmektedir. Evlilik doyumunun fedakârlık doyumu (Aydoğan ve Özbay, 2018) ve özgecil aşk tarzı (Lin ve Huddleston-Cassas, 2005; Martin vd., 1990) ile yakından ilişkili olduğu göz önünde bulundurulduğunda özgecil aşkın, desteklediği fedakârlık davranışları aracılığıyla evlilikten alınan doyuma katkıda bulunduğu öngörülmektedir. Başka bir deyişle bu bulguların, eşi koşulsuz bir aşkla sevme ve bireysel iyi oluştan ziyade birlikte iyi oluşu önceleme eğilimi arttıkça ilişkide fedakârlıktan alınan doyumun da arttığına -dolayısıyla evlilik doyumunu desteklediğine- işaret ettiği düşünülmektedir. $\mathrm{Bu}$ tür bir aşk tarzı ve fedakârlık doyumunun Türk toplumunun kültürel normlarıyla tutarlı olduğu gözlenmektedir.

İlişkilerin devamlılığı için fedakârlık davranışında bulunmak kaçınılmaz bir gereklilik olsa da (Lambert vd., 2012), sergilenen fedakârlığın altında yatan motivasyonel durumların belirlenmesi de önemlidir. Özellikle ilişki güçlendirme söz konusu olduğunda bu motivasyonel durumun biliniyor olması daha büyük önem taşımaktadır. Şimdiki araştırmanın sonuçları, özgecil aşk tarzının ilişki içinde sergilenen fedakârlık davranışlarından alınan doyumda önemli bir motivasyon kaynağı işlevi gördüğünü göstermektedir. Özgecil aşk tarzı kişinin, partnerinin hedeflerine ulaşması için fedakârlık yapmaya kendiliğinden gönüllü olduğu ve partneri mutlu oldukça mutlu olduğu yakın bir ilişsi deneyimini betimlemektedir (Lee, 1977/1973; Hendrick ve Hendrick, 1986). Çalışma kapsamında elde edilen bulgular, bireyleri yapilan fedakârlıktan doyum almaya sevk eden özgecil aşkın yaklaşma motivasyonu ile ilişkili olduğunu düşündürmektedir. Özellikle Visserman ve diğerlerinin (2017) öne sürdüğü fedakârlık motivasyonları modeli göz önünde bulundurulduğunda bu aşk tarzının partner odaklı bir 
yaklaşma motivasyonuna karşılık geldiği söylenebilir. Yaklaşma motivasyonu partnerin mutluluğunu ve ilişkideki yakınlığı arttırmayı hedeflemektedir. Sonuçları itibariyle de pozitif duygular deneyimlemeyi, yaşamdan daha fazla doyum almayı, daha kaliteli bir ilişki deneyimlemeyi ve daha az ilişkisel çatışma yaşamayı beraberinde getirmektedir (Impett vd., 2005).

Araştırma bulguları ayrıca yaşanılan acıları, üzüntü verici olayları ve talihsizlikleri sabırla katlanılması gereken olgunlaştırıcı birer yaşam tecrübesi ve hakiki mutluluğa giden yoldaki imtihanlar olarak görme eğilimi arttıkça evlilikte sergilenen fedakârlıklardan alınan doyumun da arttığını göstermektedir. $\mathrm{Bu}$ bulgu acının dönüştürücü gücüne ilişkin inançların evlilik ilişkisine spritüal bir güç olarak yansıdığını imlemektedir. Romantik ilişkilerde fedakârlık davranışının, geleceği olan bir çift olma hissine bağlı olarak ortaya çıktığ önünde bulundurulduğunda (Stanley ve Markman, 1992); acının dönüştürücü gücüyle ilgili inançların geleceğe ve daha anlamlı bir hayat sürmeye dönük örtük bir umut duygusunu içermesi nedeniyle fedakârlık konusunda motivasyonel bir değişim yarattığ (Fincham ve Beach, 1999; Lambert vd., 2012) ve yaklaşma motivasyonuyla açıklanan sağlıklı fedakârlık davranışlarını harekete geçirdiği düşünülebilir.

\subsection{Sınırlılıklar, Güçlü ve Zayıf Yönler}

Şimdiki çalışmanın çeşitli sınırlılıkları vardır. Çalışmanın nitel kısmının sınırlılığı fedakârlık davranışlarının incelenmesinde katılımcılardan yalnızca kendi yaptıkları fedakârlık davranışlarını listelemesinin istenmesidir. Onlara partnerlerinin de benzer fedakârlık davranışları sergileyip sergilemediği ya da ne tür fedakârlık davranışları sergilediği sorusu yöneltilmemiştir. Benzer şekilde bireylere bu fedakârlık davranışlarını hangi niyetle/amaçla yaptığı ya da partnerlerinin yaptığı fedakârlıkları nasıl değerlendirdiği sorulmamıştır. Sonraki araştırmaların, evlilik ilişkisindeki fedakârlık davranışlarının doğasını daha derinden anlamaya katkıda bulunmak için bu noktalar üzerinde durmasına ihtiyaç vardır.

Çalışmanın nicel kısmının da çeşitli sınırlılıkları vardır. Bunlardan ilki araştırma türüyle ilgilidir. Şimdiki araştırma kesitsel bir çalışmadır ve bu nedenle evlilik ilişkisindeki fedakârlık davranışlarının zaman içindeki seyrini takip etme ve bu seyirde özgecil aşk ve acının dönüştürücü gücüne ilişkin inançların rolünü incelemede sınırlı kalmıştır. Dolayısıyla sonraki çalışmaların boylamsal olarak yürütülmesine ihtiyaç vardır.

Bir diğer sınırlılık veri toplama yöntemiyle ilgilidir. Araştırmada çevrimiçi veri toplama tekniklerine başvurulmuştur. Öz-bildirime dayanan veri toplama araçları çevrimiçi formlar haline getirilmiş ve katılımcılara çevrimiçi anket sitesi aracılığıyla ulaşılmıştır. Bu durum ilk bakışta bir sınırlılık gibi gözükse de aynı zamanda araştırmanın güçlü yönünü oluşturmaktadır. Zira yakın ilişki araştırmalarının birçoğu, uygun örnekleme yöntemi kullanılarak üniversite öğrencilerinden toplanmaktadır. Oysa bu çalışma genel popülasyondan veri toplayarak bu sınırlılığı aşmaktadır. Ayrıca verilerin bu yolla toplanması katılımcılara, rahat hissettikleri ve kendi seçtikleri bir ortam, zaman ve konforda evliliklerindeki ilişkisel dinamikleri gözden geçirme imkânı sunmuştur.
Son olarak şimdiki çalışma evlilikte fedakârlık, fedakârlık doyumu, özgecil aşk ve acının dönüştürücü gücü değişkenlerini yalnızca tek bir kültürel bağlamda incelemiştir. Gelecek araştırmaların kültürlerarası karşılaştırmalar yapmaya imkân verecek şekilde tasarlanması fedakârlığın doğasını ve işlevlerini anlamak açısından alanyazına zengin katkılarda bulunacaktır.

Yukarıda bahsi geçen çeşitli sınırlılıklara sahip olsa da bu çalışma, evli bireyleri fedakârlık davranışı yapmaya sevk eden içsel güçlerin anlaşılmasına sağladığı katkı nedeniyle dikkate değerdir. Aynı zamanda kültürel bağlamda hangi davranışların fedakârlık olarak tanımlandığı konusunda ülkemiz açısından bir ön çalışma niteliği taşımaktadır. Ayrıca kişinin iç dünyasında acıya yüklediği pozitif anlamların evlilik ilişkisine de aksettiğini ve yaptığı fedakârlıkları bir doyum kaynağı olarak görmesine katkıda bulunduğunu göstermesi bakımından hem çift ve aile danışmanlığına hem pozitif psikoloji disiplinine hem de yakın ilişkiler psikolojisi alanına üzerinde dikkatle durulması gereken bulgular sunmaktadır.

\section{Kaynakça}

Aron, A., Aron, E. N. ve Smollan, D. (1992). Inclusion of Other in the Self Scale and the structure of interpersonal closeness. Journal of Personality and Social Psychology, 63(4), 596-612.

Aron, A., Aron, E. N., Tudor ve M. Nelson, G. (1991). Close relationships as including other in the self. Journal of Personality and Social Psychology, 60(2), 241-253.

Aron, A., Mashek, D. J. ve Aron, E. N. (2004). Closeness as including other in the self. D. J. Mashek ve A. Aron (Ed.), Handbook of closeness and intimacy (s. 27-42) içinde. Manwah, NJ: Lawrence Erlbaum Associates Inc.

Aydoğan, D. ve Özbay, Y. (2018). Evlilikte fedakârlık doyumunun ilişkisel özgünlük ve evlilik doyumu bağlamında değerlendirilmesi. Uluslararası Türkçe Edebiyat Kültür Eğitim Dergisi, 7(2), 1276-1290.

Bahr, D. B. ve Bahr, K. S. (2001). Families and selfsacrifice: Alternative models and meanings for family theory. Social Forces, 79(4), 1231-1258.

Bar-Tal, D. (1976). Prosocial behavior. Washington, DC: Hemisphere Publishing Corporation.

Baron, R. M. ve Kenny, D. A. (1986). The moderatormediator variable distinction in social psychological research: Conceptual, strategic, and statistical considerations. Journal of Personality and Social Psychology, 51(6), 1173-1182.

Batson, D., Bolen, M. H., Cross, J. A. ve Neuringer-Benefiel, H. E. (1986). Where is the altruism in the altruistic personality? Journal of Personality and Social Psychology, 50(1), 212-220.

Bilgin, R. (2016). Geleneksel ve modern toplumda kadın bedeni ve cinselliği. Firat Üniversitesi Sosyal Bilimler Dergisi, 26(1), 219-243.

Büyükşahin, A. ve Hovardaoğlu, S. (2004). Çiftlerin aşka ilişkin tutumlarının Lee'nin çok boyutlu aşk biçimleri 
kapsamında incelenmesi. Türk Psikoloji Dergisi, 19(54), 59-72.

Clark M. S. ve Mills, J. (1979). Interpersonal attraction in exchange and communal relationships. Journal of Personality and Social Psychology, 37(1), 12-24.

Creswell, C. (2017). Eğitim araştırmalarl: Nicel ve nitel araştırmanın planlanması, yürütülmesi ve değerlendirilmesi (H. Ekşi, Çev. Ed.). İstanbul: EDAM Yayınları.

Day, L. C. ve Impett, E. A. (2017). Giving when it costs: How inter-dependent self-construal shapes willingness to sacrifice and satisfaction with sacrifice in romantic relationships. Journal of Social and Personal Relationships, 35(5), 722-742.

Dinçer, D. (2017). Romantik ilişkilerde ilişki doyumunu ve yaşam doyumunu yordayan etmenler: İki Boyutlu İlişkisel Benlik Değişimi Modeli (Yayımlanmamış Doktora Tezi). Marmara Üniversitesi, İstanbul.

Dinçer, D. (2018). Power of suffering. D. A. Leeming, (Ed.), Encyclopedia of Psychology \& Religion içinde. Berlin, Heidelberg: Springer. Doi: https://doi.org/10.1007/978-3642-27771-9_200188-1

Dinçer, D., Ekşi, H. ve Aron, A. (2018). Two new scales in the field of couples and marriage counseling: The inclusion of other in the self scale and Turkish selfchange in romantic relationships scale. SHS Web of Confereces, 48, 1-7.

Dinçer, D., Ekşi, H., Demirci, I. ve Kardaş, S., (2015), Acının Dönüştürücü Gücü Ölçeği: Geçerlik ve Güvenirlik Çalışması. The Journal of Academic Social Science Studies, 39, 409-421.

Dion, K. L. ve Dion, K. K. (1996). Cultural perspectives on romantic love. Personal Relationships, 3(1), 5-17.

Eagly, A. H. ve Wood, W. (1999). The origins of sex differences in human behavior: Evolved dispositions versus social roles. American Psychologist, 54(6), 408423.

Edgar, D. ve Glezer, H. (1994). Family and intimacy: Family careers and the reconstruction of private life. International Social Science Journal, 46(1), 117-139.

Ekşi, H., Dinçer, D. ve Akalp, C. (2017, Nisan). The relationships of parental rearing behaviors, fear of happiness, and transformative power of suffering. 8th World Conference on Psychology, Counseling, and Guidance, Antalya, Türkiye'de sunulan bildiri. Özet https://drive.google.com/file/d/0B2ALYHsCTIQ3ZGo 5UHgxSmZvNmM/view adresinden alınd1.

Erikson, E. H. (1982/2014). İnsanın 8 evresi. İstanbul: OkuyanUs Yayıncılık.

Ewart, C. K., Taylor, C. B., Kraemer, H. C. ve Agras, W. S. (1991). High blood pressure and marital discord: Not being nasty matters more than being nice. Health Psychology, 10(3), 155-163.

Fehr, B. ve Russell, J. A. (1991). A concept of love viewed from a prototype perspective. Journal of Personality and Social Psychology, 60(3), 425-438.
Fincham, F. D. ve Beach, S. R. (1999). Marital conflict: Implications for working with couples. Annual Review of Psychology, 50(1), 47-77.

Gable, S. L. ve Reis, H. T. (2001). Appetitive and aversive social interaction. J. Harvey ve A. Wenzel (Ed.), Close romantic relationships: Maintenance and enhancement (s. 169-194) içinde. Mahwah, NJ: Erlbaum.

Gilligan, C. (2017). Kadının farklı sesi: Psikolojik kuram ve kadının gelişimi (Dinçer, M. Elma ve F. Arısan, Çev.). İstanbul: Pinhan Yayıncilık.

Günindi-Ersöz, A. (2015). Özel alan/kamusal alan dikotomisi: Kadınlığın "doğası" ve kamusal alandan dışlanmışlığg. Sosyoloji Araştırmaları Dergisi, 18(1), 80-102.

Hatfield, E. ve Sprecher, S. (1986) Measuring passionate love in intimate relationships. Journal of Adolescence, 9(4), 383-410.

Hendrick, C. ve Hendrick, S. S. (1986). A theory and method of love. Journal of Personality and Social Psychology, 50(2), 392-402.

Hendrick, S. S. ve Hendrick, C. (1987). Love and sex attitudes and religious beliefs. Journal of Social and Clinical Psychology, 5(3), 391-398.

Hendrick, C. ve Hendrick, S. S. (1990). A relationshipspecific version of The Love Attitudes Scale. Journal of Social Behavior \& Personality, 5(4), 239-254.

Hendrick, C., Hendrick, S. S. ve Dicke, A. (1998). The Love Attitudes Scale: Short form. Journal of Personal and Social Relationships, 15(2), 147-159.

Hill, R. P. (2002). Compassionate love, agape, and altruism: A new framework for understanding and supporting impowerished consumers. Journal of Macromarketing, 22(1), 19-31.

Impett, E. A., Gable, S. L. ve Peplau, L. A. (2005). Giving up and giving in: The costs and benefits of daily sacrifice in intimate relationships. Journal of Personality and Social Psychology, 89(3), 327-344.

Impett, E. A. ve Gordon, A. (2008). For the good of others: Toward a positive psychology of sacrifice. S. J. Lopez (Ed.), Positive psychology: Exploring the best in people (s. 79-100) içinde. Westport, CT: Greenwood Publishing.

Jack, D. C. (1991). Silencing the self: Women and depression. Cambridge, MA: Harvard University Press.

Jayawickreme, E. ve Blackie, L. E. R. (2016). Exploring the psychological benefits of hardship: A critical reassessment of posttraumatic growth. Springer: Nottingham, UK.

Johnson, M. P., Caughlin, J. P. ve Huston, T. L. (1999). The tripartite nature of marital commitment: Personal, moral, and structural reasons to stay married. Journal of Marriage and the Family, 61(1), 160-177.

Joseph, S. ve Linley, P. A. (2008). Psychological assessment of growth following adversity: A review. S. Joseph ve P. A. Linley (Ed.), Trauma, recovery, and growth: Positive psychological perspectives on posttraumatic 
stress (s. 21-36) içinde. Hoboken, NJ: John Wiley \& Sons Inc.

Joshanloo, M., (2014), Differences in the endorsement of various conceptions of well-being between two Iranian groups, Psychology of Religion and Spirituality, 6(2): 138-149.

Joshanloo, M. (2015). Conceptions of happiness and identity integration in Iran: A situated perspective. Middle East Journal of Positive Psychology, 1(1), 24-35.

Kanemasa, Y., Taniguchi, J., Daibo, I. ve Ishimori, M. (2004). Love styles and romantic love experiences in Japan. Social Behavior and Personality: An International Journal, 32(3), 265-282.

Kelley, H. H. (1991). Lewin, situations, and interdependence. Journal of Social Issues, 47(2), 211233.

Kelley, H. H. ve Thibault, J. (1978). Interpersonal relations: A theory of interdependence. New York, NY: Wiley.

Killen, M. ve Turiel, E. (1998). Adolescents' and young adults' evaluations of helping and sacrificing for others. Journal of Research on Adolescence, 8(3), 355-375.

Kogan, A., Impett, E., Oveis, C., Hui, B., Gordon, A. ve Keltner, D. (2010). When gives feels good: The intrinsic benefits of sacrifice in romantic relationships for the communally motivated. Psychological Science, 2l(12), 1918-1924

Lambert, N. M., Fincham, F. D. ve Stanley, S. (2012). Prayer and satisfaction with sacrifice in close relationships. Journal of Social and Personal Relationships, 29(8), 1058-1070.

Lee, J. A. (1975). Romantic heresy. Canadian Review of Sociology, 12(4), 514-528.

Lee, J. A. (1977). A typology of styles of loving. Personality and Social Psychology Bulletin, 3(2), 173-182.

Lee, J. A. (1977/1973). The colors of love (3. Bask1). New York, NY: Bantam Books.

Lerner, H. G. (1988). Women in therapy. New York, NY: Perennial Library.

Levine, R., Sato, S., Hashimoto, T. ve Verma, J. (1995). Love and marriage in eleven cultures. Journal of CrossCultural Psychology, 26(5), 554-571.

Levinger, G. (1980). Toward the analysis of close relationships. Journal of Experimental Social Psychology, 16(6), 510-544.

Lin, L. ve Huddleston-Casas, C. A. (2005) Agape love in couple relationships, Marriage \& Family Review, 37(4), 29-48.

Martin, J. D., Blair, G. E., Nevels, R. ve Fitzpatrick, J. H. (1990). A study of the relationship of styles of loving and marital happiness. Psychological Reports, 66(1), 123-128.

Montgomery, M. J. ve Sorell, G. T. (1997). Differences in love attitudes across family life stages. Family Relations: An Interdisciplinary Journal of Applied Family Studies, 46(1), 55-61.
Neff, K. D. ve Harter, S. (2002). The authenticity of conflict resolutions among adult couples: Does women's otheroriented behavior reflect their true selves? Sex Roles, 47(9-10), 403-412.

Noller, P. (1996). What is this thing called love? Defining the love that supports marriage and family. Personal Relationships, 3(1), 97-11.

Page, J. R., Stevens, H. B. ve Galvin, S. L. (1996). Relationships between depression, self-esteem, and self-silencing behavior. Journal of Social and Clinical Psychology, 15(4), 381-396.

Pam, A., Plutchik, R. ve Conte, H. (1973). Love: A psychometric approach. Proceedings of the 81st Annual Convention of the American Psychological Association, 159-160.

Rubin, Z. (1970). Measurement of romantic love. Journal of Personality and Social Psychology, 16(2), 265-273.

Rusbult, C. E., Verette, J., Whitney, G., Slovik, L. ve Lipkus, I. (1991). Accommodation processes in close relationships: Theory and preliminary empirical evidence. Journal of Personality and Social Psychology, 60(1), 53-78.

Sakall1-Ugurlu, N ve Türkoğlu， B. (2017). Günümüz Türkiye'sinde cinsiyet kalıpyargıları: Kadın kimdir? Erkek kimdir? D. Kökdemir ve Z. Yeniçeri (Ed.), 1. Sosyal Psikoloji Kongresi (s. 98-107) içinde. Ankara: Başkent Üniversitesi.

Scrutton, A. P. (2015). Suffering as potentially transformative: A philosophical and pastoral consideration drawing on Henri Nouwen's experience of derpression. Pastoral Psychology, 64(1), 99-109.

Shaver, C. ve Hazan, P. (1987). Romantic love conceptualized as an attachment process. Interpersonal Relations and Group Process, 52(3), 511-524.

Sprecher, S. ve Toro-Morn, M. (2002). A study of men and women from different sides of earth to determine if men are from Mars and women are from Venus in their beliefs about love and romantic relationships. Sex Roles, 46(5-6), 131-147.

Stanley, S. M. ve Markman, H. J. (1992). Assessing commitment in personal relationships. Journal of Marriage and Family, 54(3), 595-608.

Stanley, S. M., Whitton, S. W., Sadberry, S. L., Clements, M. L. ve Markman, H. J. (2006). Sacrifice as predictor of marital outcomes. Family Process, 45(3), 289-303.

Sternberg, R. J. (1986). A triangular theory of love. Psychological Review, 93(2), 119-135.

Tedeschi, R. G. ve Calhoun, L. G. (1995). Trauma and transformation: Growing in the aftermath of suffering. Thousand Oaks, CA: Sage.

Tedeschi, R. G. ve Calhoun, L. G. (1996). The Posttraumatic Growth Inventory: Measuring the positive legacy of trauma. Journal of Traumatic Stress, 9(3), 455-471.

Tedeschi, R. G. ve Calhoun, L. G. (2004). Target article: "Posttaumatic growth: Conceptual foundations and emprical evidence". Psychological Inquiry, 15(1), 1-18. 
Thompson, B. ve Borello, G. M. (1992). Measuring secondorder factors using confirmatory methods: An illustration with the Hendrick-Hendrick love instrument. Educational and Psychological Measurement, 52(1), 69-77.

Topcu, Ç., ve Tezer, E. (2013). Fedakârlık ta Algılanan Zarar Ölçeği ve Fedakârlık Doyum Ölçeği'nin Türkçe'ye adaptasyonu. Türk Psikolojik Danışma ve Rehberlik Dergisi, 5(40), 176-185.

Triandis, H. C. (1993). Collectivism and individualism as cultural syndromes. Cross-Cultural Research, 27(3-4), 155-180.

Whitton, S. W., Stanley, S. M. ve Markman, H. J. (2007). If I help my partner, will it hurt me? Perceptions of sacrifice in romantic relationships. Journal of Social and Clinical Psychology, 26(1), 64-91.

Wood, W. ve Eagly, A. H. (2002). A cross-cultural analysis of the behavior of women and men: Implications for the origins of sex differences. Psychological Bulletin, 128(5), 699-727.
Van Lnge, P. A., Agnew, C. R., Harinck, F. ve Steemers, G. E. M. (1997). From game theory to real life: How social value orientation affects willingness to sacrifice in ongoing close relationships. Journal of Personality and Social Psychology, 73(6), 1330-1344.

Van Lange, P. A. M., Rusbult, C. E., Drigotas, S. M., Arriaga, X. A., Witcher, B. S. ve Cox, C. L. (1997). Willingness to sacrifice in close relationships. Journal of Personality and Social Psychology, 72(6), 13731395.

Visserman, M. L., Righetti, F., Impett, E. A., Keltner, D. ve Van Lange, P. A. M. (2017). It's the motive that counts: Perceived sacrifice motives and gratitude in romantic relationships. Emotion 18(5), 625-637.

Yaman, K. G. ve Eryiğit, D. (2018). Psikolojik danışmanlar ve özel eğitim öğretmenlerinin eş tükenmişliğinin fedakârlık tan algılanan zarar, fedakârlık doyumu ve duygu düzenleme güçlüğü değişkenleri 1şı̆̆ında incelenmesi, Ĕgitim ve Ögretim Araştırmaları Dergisi, 7(1), 60-68. 